\title{
Health Behavior and Health Status of Adults in Rural Areas of Sumbawa Prefecture, West Nusa Tenggara Province, Indonesia
}

\author{
Keiko NAGAI ${ }^{1}$, Megumi HIRAYAMA², Satoshi TOYOKAWA ${ }^{3}$ and Katsumi KANO²
}

The aim of the current study was to clarify the general situation of health behavior and health status of adults in rural areas of Sumbawa Prefecture, West Nusa Tenggara Province, Indonesia, and to assess the indirect influence of development assistance. The participants consisted of 200 inhabitants from two villages, with a total of 100 men and 100 women. One village, Maronge, had benefited from a development assistance project and the other, Lesen, served as the control area. A structured interview survey was carried out. The questionnaire included 61 items such as demography, economic status, health-related lifestyle, sanitary conditions, involvement of health-related community activities, health care-seeking behavior, dietary habits, and health status. Forty seven of these were analysed for the study.

Adults in rural areas may have a healthy lifestyle. For example, they may exercise regularly, eat breakfast every day, and have a normal body weight. However, they might have diseases that do not appear in health statistics, such as silu. Significant differences were observed in economic status, physical exercise, smoking, dietary habit, obesity, and care-seeking behavior between the two villages. In Maronge, economic status was higher, more cigarette were smoked, and body mass index (BMI) was higher. Diabetes mellitus and hypertension were also seen. In Lesen, frequency of fish or meat intake was lower and fewer women had regular exercises habit. The current study suggests that development assistance influenced health behavior and health status through income generation.

Key words : health behavior, adults, Indonesia, development, questionnaire

\section{Introduction}

Development assistance often brings about a rapid change in the economic status of benefited areas, and it tends to cause lifestyle changes in the inhabitants. From an anthropological point of view, development assistance functions as an ex- ternal pressure to accelerate change in indigenous cultures (Kikuchi, 1998). The World Bank (1994) reported that development assistance improves the quality of life in benefited areas. Development assistance is therefore likely to affect health behavior through improvements in income generation and health status. Such an indi-

${ }^{\prime}$ Graduate School of Medical Science, University of Tsukuba

IIIstitute of Community Medicine, University of Tsukuba

${ }^{8}$ Graduate School of Medicine, The University of Tokyo 
rect influence of development assistance has not been considered because it is difficult to determine (Sato H, 1996).

The previous studies on health behavior and health status in developing countries targeted the control of infectious diseases, and maternal and child health programs or users of medical services in urban areas. In Indonesia, studies on health behavior and health status involved infants, children and women of reproductive age (Strisna et al., 1993; Sularyo, 1996; Persson et al., 2001; Launer and Habichit, 1989), patients with infectious diseases (Sudomo et al., 1993; Toma et al., 1999; Karyadi et al., 2000; Roosiherimate et al., 2000; Saw et al., 2001), and inhabitants in urban areas (Darmojo, 1993; Kaye and Novell, 1994; Juguan et al., 1999; Wakai et al., 2000).

The current study has two aims: to clarify health behavior and health status in rural areas, and to assess the indirect influence of development assistance on improving health behavior and status.

\section{Subjects and Methods}

The study was conducted in Sumbawa Prefecture, West Nusa Tenggara Province, Indonesia (Map 1) from June 20 to July 13, 2001. The target areas were selected from the rural regions.
Maronge was selected from the benefited areas of the small-scale irrigation management project, and Lesen was selected as the control area. The project has been implemented by Japanese official development assistance since 1990 for agricultural and rural development in dry areas in eastern Indonesia. The project components included water resources development, irrigation facilities construction and on-farm training to stabilize the rice harvest. Most of the inhabitants in both villages were Sumbawans who were Muslims.

The main industry of both villages was agriculture, specifically paddy and mung bean cultivations. Maronge is located 40 kilometers away from Sumbawa Besar, the capital of the Sumbawa Prefectrure. The journey takes about 1.5 hours by public transportation. Maronge consists of three "dusun" or sub-villages whose population totaled 4,468. The population was made up of 1,131 households (Badan Pusat Statistik Kabupaten Sumbawa, 1999). Most of farmers in Maronge started double cropping of rice and some of them began vegeculture in 1997 when irrigation water from the Tieu Kulit Dam, which constructed in 1994 as one of the components of the project, was started to supply. Lesen is located 15 kilometers away from Sumbawa Besar, but

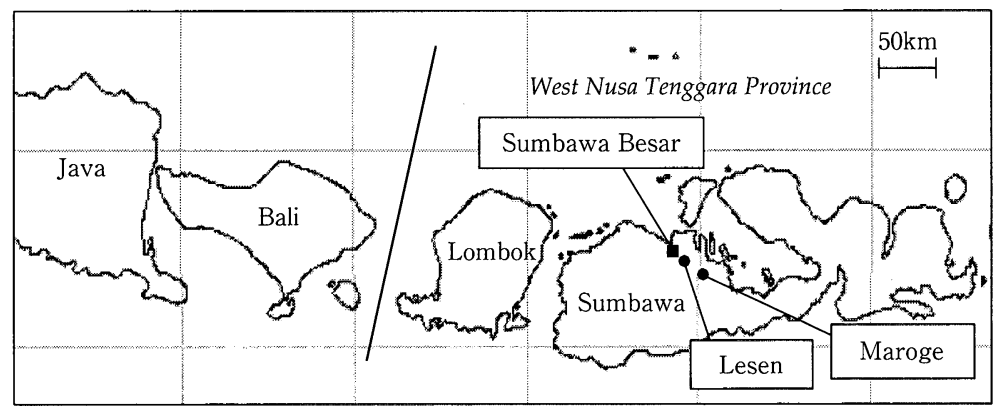

Map 1 Maronge and Lesen Villages in Sumbawa Island, Indonesia 
it took about 1.5 hours by public transportation because of rough roads. Lesen consisted of 5 dusun, 590 households, and a population of 2,356 (Badan Pusat Statistik Kabupaten Sumbawa, 2000). Most of the farmers in Lesen could harvest rice only once a year, and mung bean growing was unstable because of water shortages.

Participants consisted of 100 inhabitants (50 men and 50 women) from each village, 20 to 70 years old. One interviewer conducted the survey. The interviewer visited inhabitants' homes randomly and asked for their participation after explaining the purpose of the current study and the rights of the participants. Only the inhabitants who consented to cooperate were chosen to participate. In some case, both man and woman in the same household were interviewed. The interviews were carried out with a questionnaire written in Indonesian.

The questionnaire consisted of demography $(6$ items), economic status (3 items), health-related lifestyle (14 items), sanitary conditions (4 items), care-seeking behavior (4 items), involvement in health related community activities (5 items), dietary habit ( 2 items), and health status (23 items). Basic queries were referred to the questionnaire
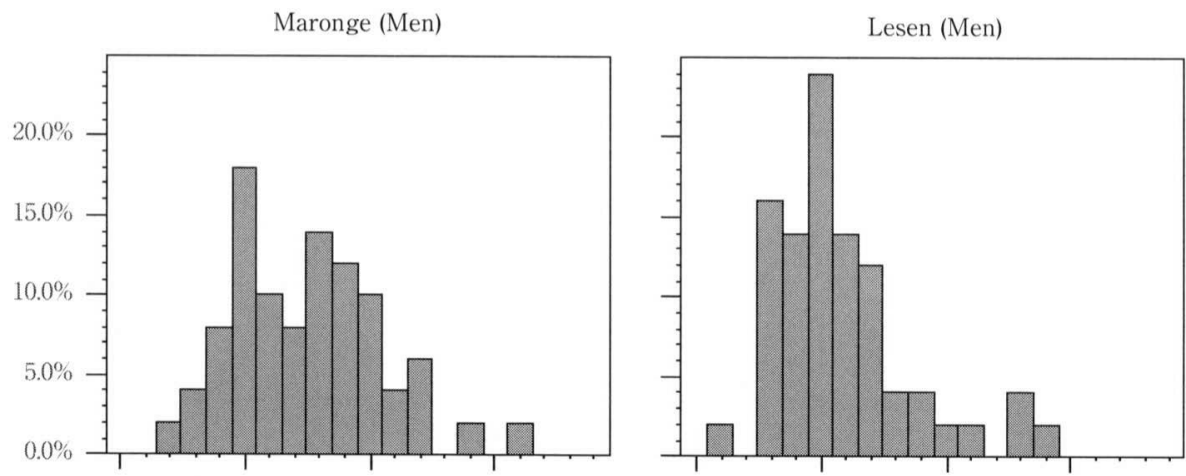

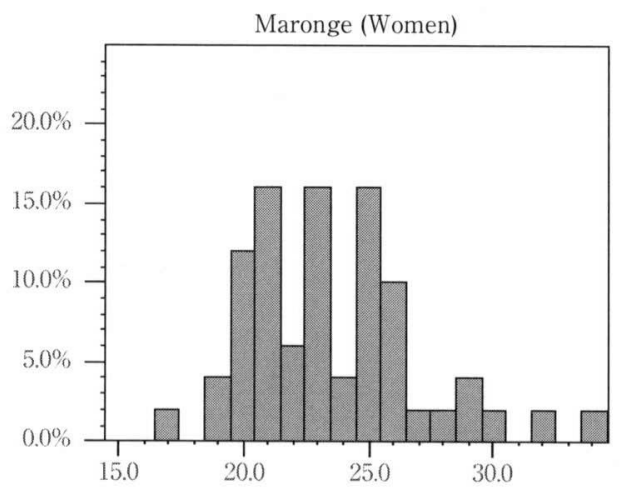

BMI $\left(\mathrm{kg} / \mathrm{m}^{2}\right)$

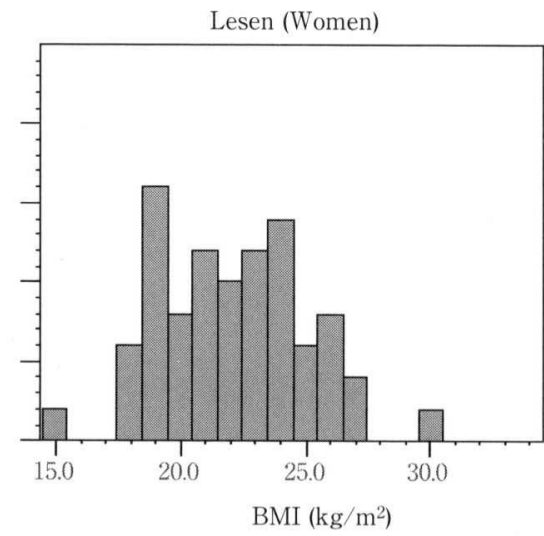

Fig. 1 Distribution of Body Mass Index (BMI)

Mean \pm SD (Standard Deviation) of BMI were $22.5 \pm 3.0 \mathrm{~kg} / \mathrm{m}^{2}$ for men and $23.6 \pm 3.5 \mathrm{~kg} / \mathrm{m}^{2}$ for women in Maronge, and $20.8 \pm 2.7 \mathrm{~kg} / \mathrm{m}^{2}$ for men and $22.1 \pm 3.1 \mathrm{~kg} / \mathrm{m}^{2}$ for women in Lesen (men $\mathrm{p}=0.003$, women $\mathrm{p}=0.029$ ). 
used for the Indonesia Demographic and Health Survey 1997 (Badan Pusat Statiskik, et al., 1998). Queries regarding demography consisted of sex, age, education, occupation, religion and place of birth. Economic status was described for annual income, number of times of paddy harvest per year, and opinion about income in these five years. Health-related lifestyle referred to the seven lifestyle habits of Breslow (Berkman and Breslow L, 1983). The habits are physical exercise, smoking behavior, obesity, alcohol drinking behavior, hours of sleeping, eating breakfast and eating between meals. Obesity was calculated from the body mass index (BMI) $\left(\mathrm{kg} / \mathrm{m}^{2}\right)$, which was calculated from body weights and heights. The interviewer measured body weight in $500 \mathrm{~g}$ units using a digital scale on a flat floor and height in centimeters. Body height was measured using a tape measure lengthened from heel to pileum of the participant standing on a flat floor by the wall. Sanitary conditions were judged by the presence of rest rooms and sources of clean drinking water. Involvement in health-related community activities was described from current involvement, involvement period, kind of activities and acquirement of knowledge on health. Care-seeking behavior was described for the following four cases: assumptions in slight sickness and serious sickness, actual behavior in past sickness, and toothache. Queries regarding dietary habits consisted of the frequency of intake of rice, meat or fish, eggs, milk, soybean products (tahu- like Japanese tohu/ tempe- like Japanese natto), vegetables and fruits, which are recommended in a guideline of the Ministry of Health (Departemen Kesehatan, 1995). Queries on health status consisted of subjective health status, basic physical condition, and experience of serious sickness. At the end of interview, blood pressure was measured once using a wrist type automated sphygmomanometer by the interviewer. Queries on basic physical condition were prepared based on primary patient diagnosis (Tamura, 1996). The questionnaire was finalized using the results of a preliminary interview done in November 2000. The Indonesian version was edited by native Indonesians and re-translated to Japanese to insure that there was no difference between the Japanese and Indonesian versions.

Forty seven items on demography, economic status, health-related lifestyle, care-seeking behavior, dietary habits and health status were analysed. We used a chi-square test or Fisher's exact test for comparison of categorical valuables and the Student's t-test for differences of the means of continuous valuables. A value of $\mathrm{p}<0.05$ was considered statistically significant; all tests were conducted by two-sided. Statistical analyses except Fisher's exact test were performed with the statistical package SPSS 10.0J for Windows. Fisher's exact tests were performed with the Statistical Analyses System (SAS).

\section{Results}

There were no significant differences in mean age. More women in Maronge (5 people) did housekeeping work exclusively than in Lesen (1 person). Educational background of men in Maronge tended to be higher than men in Lesen (Table 1). The income in Maronge was significantly higher than in Lesen (men $\mathrm{p}<0.001$, women $\mathrm{p}<0.001$ ). In Maronge, $92.0 \%$ of men and $84.0 \%$ of women harvested paddies twice a year. Ninety percent of men and $75.5 \%$ of women felt their income had been increased in the last five years. By contrast, income in Lesen was lower. Seventy eight percent of men and $84.0 \%$ of women stated that their income had decreased 
Table 1 Age, educational background, and occupation of the participants

\begin{tabular}{|c|c|c|c|c|c|c|}
\hline & \multicolumn{2}{|c|}{ Maronge } & \multicolumn{2}{|c|}{ Lesen } & \multicolumn{2}{|c|}{ p value ${ }^{1)}$} \\
\hline & $\begin{array}{c}\text { Men } \\
(n=50)\end{array}$ & $\begin{array}{l}\text { Women } \\
(\mathrm{n}=50)\end{array}$ & $\begin{array}{c}\text { Men } \\
(\mathrm{n}=50)\end{array}$ & $\begin{array}{l}\text { Women } \\
(\mathrm{n}=50)\end{array}$ & Men & Women \\
\hline Age（year） & & & & & 0.328 & 0.086 \\
\hline mean $\pm \mathrm{SD}^{2)}$ & $40.6 \pm 10.2$ & $40.3 \pm 11.6$ & $38.4 \pm 11.7$ & $37.1 \pm 10.2$ & & \\
\hline Educational background ${ }^{3)}$ & & & & & $<0.001 *$ & 0.660 \\
\hline - no school/elementary drop out & $3(6.0 \%)$ & $11(22.0 \%)$ & $9(18.0 \%)$ & $15(30.0 \%)$ & & \\
\hline - elementary & $17(34.0 \%)$ & $17(34.0 \%)$ & $35(70.0 \%)$ & $30(60.0 \%)$ & & \\
\hline$\cdot$ secondary & $7(14.0 \%)$ & $4(8.0 \%)$ & $3(6.0 \%)$ & $2(4.0 \%)$ & & \\
\hline - high school/higher & $23(46.0 \%)$ & $18(36.0 \%)$ & $3(6.0 \%)$ & $3(6.0 \%)$ & & \\
\hline Occupation & & & & & 0.436 & $0.031^{*}$ \\
\hline · farmer & $45(90.0 \%)$ & $42(84.0 \%)$ & $48(96.0 \%)$ & $49(98.0 \%)$ & & \\
\hline - others ${ }^{4)}$ & $5(10.0 \%)$ & $8(16.0 \%)$ & $2(4.0 \%)$ & $1(2.0 \%)$ & & \\
\hline \multicolumn{7}{|c|}{$\begin{array}{l}\text { * }: p<0.05 \\
\text { 1) Differences in the means of age were tested by the Student's t-test. } \\
\text { Comparison of educational background was tested by a chi-square test. } \\
\text { Comparison of occupation was tested by the Fisher's exact test. } \\
\text { 2) Standard Deviation } \\
\text { 3) Educational system in Indonesia is basically } 6 \text { years in elementary school (compulsory), } 3 \text { years in junior high school, } \\
3 \text { years in high school, and various higher education including vocational school, college, and university. } \\
\text { 4) "Others" including official, employee, retailer, housewife and no job. }\end{array}$} \\
\hline
\end{tabular}

Table 2 Comparison of economic status (annual household income, annual crop of paddy and opinion of difference in income in these five years)

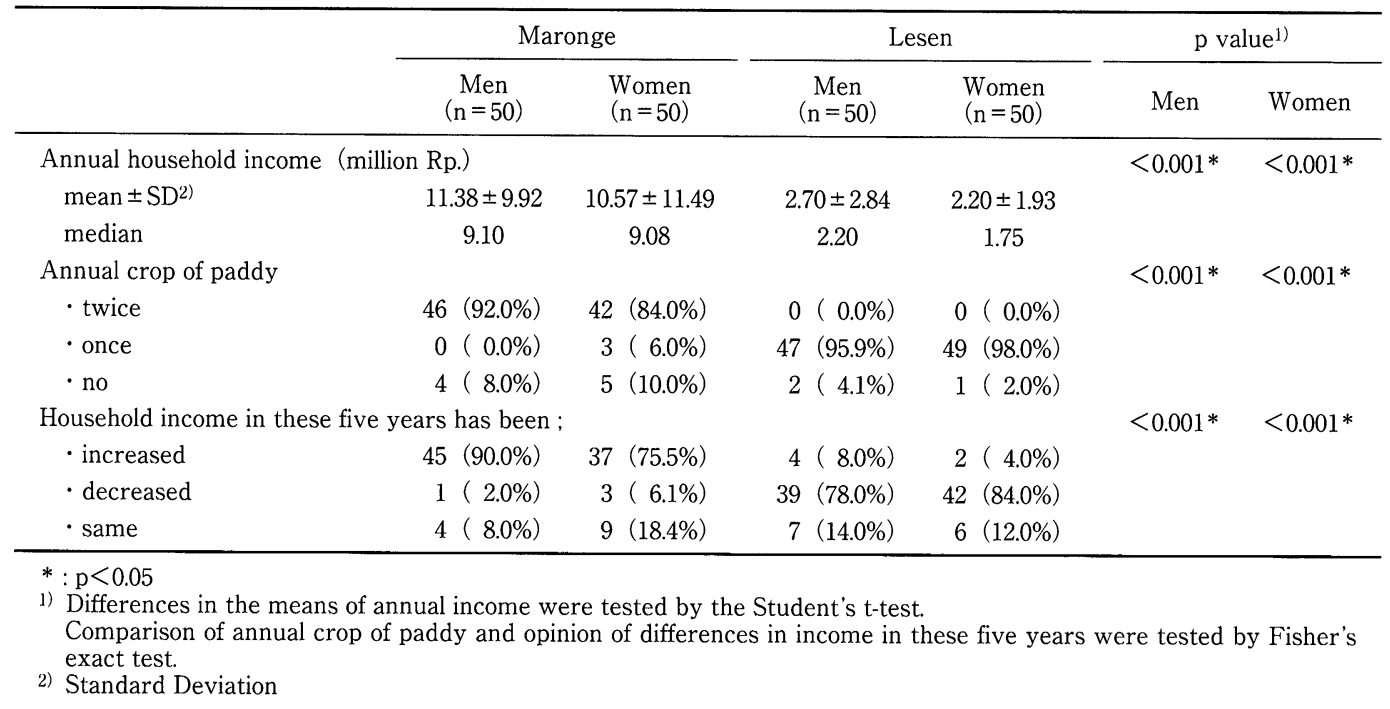

in these same five years (Table 2).

Table 3 shows a comparison of health-related lifestyle in the two villages. Fifty-two percent of men and $40.0 \%$ of women in Maronge and $56.0 \%$ of men in Lesen exercised regularly, while only $18.0 \%$ of women in Lesen did $(\mathrm{p}=0.015)$. Smoking habits of men differed significantly between the two villages. More men in Maronge smoked 
more than 1 case of cigarettes (20/case) per day. Men in Lesen tended to smoke a few hand-made cigars named "lontar". A few single men in Maronge drank wine or beer once a week or once a month regularly. Hours of sleeping in both villages were under seven hours and they were supplemented by napping. There were fewer men who napped regularly in Lesen than in Maronge $(p=0.016)$. Ninety-six percent of both men and women in Maronge and $94.0 \%$ of men and $96.0 \%$ of women in Lesen ate breakfast every day. More women in Maronge ate be-

Table 3 Comparison of practice of health-related lifestyle (physical exercises, smoking, alcohol drinking, hours of sleeping, eating breakfast and eating between-meal )

\begin{tabular}{|c|c|c|c|c|c|c|c|}
\hline & \multicolumn{3}{|c|}{ Maronge } & \multicolumn{2}{|c|}{ Lesen } & \multicolumn{2}{|c|}{$\mathrm{p}$ value ${ }^{1)}$} \\
\hline & & Men & Women & Men & Women & Men & Women \\
\hline Physical exercise & & & & & & 0.688 & $0.015^{*}$ \\
\hline$\cdot$ yes & 26 & $(52.0 \%)$ & $20(40.0 \%)$ & $28(56.0 \%)$ & $9(18.0 \%)$ & & \\
\hline$\cdot$ no & 24 & $(48.0 \%)$ & $30(60.0 \%)$ & $22(44.0 \%)$ & $41(82.0 \%)$ & & \\
\hline Smoking & & & & & & 0.334 & - \\
\hline · yes & 41 & $(82.0 \%)$ & $0(0.0 \%)$ & $37(76.0 \%)$ & $1(2.0 \%)$ & & \\
\hline$\cdot$ no & 9 & $(18.0 \%)$ & $50(100.0 \%)$ & $13(24.0 \%)$ & $49(98.0 \%)$ & & \\
\hline Quantity of smoking per day & & & & & & $<0.001^{*}$ & - \\
\hline - under 20 nos. & 11 & $(22.0 \%)$ & $0(0.0 \%)$ & $30(60.0 \%)$ & $1(2.0 \%)$ & & \\
\hline$\cdot 20$ nos. $\sim$ & 30 & $(60.0 \%)$ & $0(0.0 \%)$ & $7(14.0 \%)$ & $0(0.0 \%)$ & & \\
\hline Kind of tobacco & & & & & & $0.003^{*}$ & - \\
\hline$\cdot$ lontar/sirit2) & 7 & $(14.0 \%)$ & $0(0.0 \%)$ & $20(40.0 \%)$ & $1(2.0 \%)$ & & \\
\hline - cigarette & 28 & $(56.0 \%)$ & $0(0.0 \%)$ & $14(28.0 \%)$ & $0(0.0 \%)$ & & \\
\hline - other ${ }^{3)}$ & 6 & $(12.0 \%)$ & $0(0.0 \%)$ & $3(6.0 \%)$ & $0(0.0 \%)$ & & \\
\hline Alcohol drinking & & & & & & 0.242 & - \\
\hline - yes & 3 & $(6.0 \%)$ & $0(0.0 \%)$ & $0(0.0 \%)$ & $0(0.0 \%)$ & & \\
\hline$\cdot$ no & 47 & $(94.0 \%)$ & $50(100.0 \%)$ & $50(100.0 \%)$ & $50(100.0 \%)$ & & \\
\hline \multicolumn{8}{|l|}{ Hours of sleeping (hours) } \\
\hline mean $\pm \mathrm{SD}^{4)}$ & & $57 \pm 1.42$ & $6.53 \pm 1.11$ & $6.84 \pm 1.41$ & $6.75 \pm 1.60$ & 0.342 & 0.426 \\
\hline $\mathrm{Nap}^{5)}$ & & & & & & $0.016^{*}$ & 0.105 \\
\hline - yes & 33 & $(66.0 \%)$ & $33(66.0 \%)$ & $21(42.0 \%)$ & $25(50.0 \%)$ & & \\
\hline$\cdot$ no & 17 & $(34.0 \%)$ & $17(34.0 \%)$ & $29(58.0 \%)$ & $25(50.0 \%)$ & & \\
\hline Eating breakfast everyday $\left.{ }^{6}\right)$ & & & & & & 1.000 & 1.000 \\
\hline - yes & 48 & $(96.0 \%)$ & $48(96.0 \%)$ & $47(94.0 \%)$ & $48(96.0 \%)$ & & \\
\hline$\cdot$ no & & $(4.0 \%)$ & $2(4.0 \%)$ & $3(6.0 \%)$ & $2(4.0 \%)$ & & \\
\hline \multicolumn{8}{|l|}{ Eating between-meal everyday ${ }^{7}$} \\
\hline - yes & 17 & $(34.0 \%)$ & $31(62.0 \%)$ & $17(34.0 \%)$ & $15(30.0 \%)$ & 1.000 & $0.001^{*}$ \\
\hline$\cdot$ no & 33 & $(66.0 \%)$ & $19(38.0 \%)$ & $33(66.0 \%)$ & $35(70.0 \%)$ & & \\
\hline
\end{tabular}

* : $\mathrm{p}<0.05$

1) Differences in the means of hours of sleeping were tested by the Student's t-test. Comparison of the alcohol drinking of men and eating breakfast everyday were tested by Fisher's exact test.

Comparison of the other items were tested by a chi-square test.

2) Lontar is a kind of cigars made of dried tobacco leaves wrapped by dried lontar leaves.

Sirit is a kind of eating tobacco for elder women.

3) "others" means the participants who smoked both lontar and cigarettes.

4) Standard Deviation.

5) Nap is brief sleep in the afternoon; usually they sleep half or an hour after lunch.

6) Inhabitants in the studied areas, in general, ate meals three times per day, i.e., breakfast at around $5: 00$ to $6: 00$, lunch at noon and dinner at around 19:00.

7) Inhabitants in the studied areas, in general, ate between-meal between lunch and dinner, if they want. 
tween meals every day than in Lesen $(\mathrm{p}=0.001)$. In Maronge, $47.9 \%$ of participants tended to prefer commercial foods such as fried snacks and sweet breads to traditional snacks, whereas $9.1 \%$ of participants in Lesen did $(\mathrm{p}<0.001)$.

Mean values of BMI were $22.5 \pm 3.0 \mathrm{~kg} / \mathrm{m}^{2}$ for men and $23.6 \pm 3.5 \mathrm{~kg} / \mathrm{m}^{2}$ for women in Maronge, and $20.8 \pm 2.7 \mathrm{~kg} / \mathrm{m}^{2}$ for men and $22.1 \pm 3.1 \mathrm{~kg} / \mathrm{m}^{2}$ for women in Lesen (men $\mathrm{p}=0.003$, women $\mathrm{p}=$ 0.029). In Maronge, 10 men and 17 women were distributed over 25.0, while 5 men and 8 women in Lesen were (Figure 1).

Frequency of intake of seven foods is shown in Table 4. People in the study usually ate meals three times a day, i. e., breakfast, lunch and dinner, and they sometimes ate between meals in the afternoon. The daily diet in Maronge consists of rice, fish and vegetables. In Lesen, the daily diet consists of rice and one dish, usually fish or eggs. Ninety-six percent of men and $94.0 \%$ of

Table 4 Comparison of intake of seven foods recommended by the Ministry of Health of Indonesia (rice, fish or meat, eggs, milk, tempe or tahu, vegetables and fruits )

\begin{tabular}{|c|c|c|c|c|c|c|c|}
\hline & \multicolumn{3}{|c|}{ Maronge } & \multicolumn{2}{|c|}{ Lesen } & \multicolumn{2}{|c|}{$\mathrm{p}$ value $\mathrm{e}^{1)}$} \\
\hline & & Men & Women & Men & Women & Men & Women \\
\hline Rice & & & & & & - & - \\
\hline$\cdot$ every day²) & 50 & $(100.0 \%)$ & $50(100.0 \%)$ & $50(100.0 \%)$ & $50(100.0 \%)$ & & \\
\hline$\cdot 1 \sim 2$ times/week & 0 & $(0.0 \%)$ & $0(0.0 \%)$ & $0(0.0 \%)$ & $0(0.0 \%)$ & & \\
\hline$\cdot 1 \sim 2$ times/month or rarely & 0 & $(0.0 \%)$ & $0(0.0 \%)$ & $0(0.0 \%)$ & $0(0.0 \%)$ & & \\
\hline Fish/meat & & & & & & $<0.001 *$ & $<0.001^{*}$ \\
\hline · every day²) & 48 & $(96.0 \%)$ & $47(94.0 \%)$ & $11(22.0 \%)$ & $13(26.0 \%)$ & & \\
\hline$\cdot 1 \sim 2$ times/week & & $(4.0 \%)$ & $1(2.0 \%)$ & $38(76.0 \%)$ & $36(72.0 \%)$ & & \\
\hline$\cdot 1 \sim 2$ times/month or rarely & 0 & $(0.0 \%)$ & $2(4.0 \%)$ & $1(2.0 \%)$ & $1(2.0 \%)$ & & \\
\hline Eggs & & & & & & 0.149 & 0.063 \\
\hline · every day ${ }^{2)}$ & & $(8.0 \%)$ & $5(10.0 \%)$ & $0(0.0 \%)$ & $0(0.0 \%)$ & & \\
\hline$\cdot 1 \sim 2$ times/week & 32 & $(64.0 \%)$ & $31(62.0 \%)$ & $36(72.0 \%)$ & $37(74.0 \%)$ & & \\
\hline$\cdot 1 \sim 2$ times/month or rarely & 14 & $(28.0 \%)$ & $14(28.0 \%)$ & $14(28.0 \%)$ & $13(26.0 \%)$ & & \\
\hline Milk & & & & & & $0.002 *$ & $<0.001^{*}$ \\
\hline$\cdot$ every day ${ }^{2)}$ & & $(2.0 \%)$ & $5(10.0 \%)$ & $0(0.0 \%)$ & $0(0.0 \%)$ & & \\
\hline$\cdot 1 \sim 2$ times/week & 11 & $(22.0 \%)$ & $11(22.0 \%)$ & $1(2.0 \%)$ & $0(0.0 \%)$ & & \\
\hline$\cdot 1 \sim 2$ times/month or rarely & 38 & $(76.0 \%)$ & $34(68.0 \%)$ & $49(98.0 \%)$ & $50(100.0 \%)$ & & \\
\hline Tahu/Tempe ${ }^{3)}$ & & & & & & 0.413 & 0.068 \\
\hline · every day 2$)$ & & $(4.0 \%)$ & $5(10.0 \%)$ & $1(2.0 \%)$ & $2(2.0 \%)$ & & \\
\hline$\cdot 1 \sim 2$ times/week & 26 & $(52.0 \%)$ & $30(60.0 \%)$ & $20(40.0 \%)$ & $24(48.0 \%)$ & & \\
\hline$\cdot 1 \sim 2$ times/month or rarely & & $(44.0 \%)$ & $15(30.0 \%)$ & $29(58.0 \%)$ & $25(50.0 \%)$ & & \\
\hline Vegetables & & & & & & 0.112 & $0.021 *$ \\
\hline$\cdot$ every day 2) & 32 & $(64.0 \%)$ & $37(74.0 \%)$ & $21(42.0 \%)$ & $25(50.0 \%)$ & & \\
\hline$\cdot 1 \sim 2$ times/week & & $(32.0 \%)$ & $13(26.0 \%)$ & $26(52.0 \%)$ & $23(46.0 \%)$ & & \\
\hline$\cdot 1 \sim 2$ times/month or rarely & & $(4.0 \%)$ & $0(0.0 \%)$ & $3(6.0 \%)$ & $2(4.0 \%)$ & & \\
\hline Fruits & & & & & & $<0.001^{*}$ & $0.002 *$ \\
\hline · every day ${ }^{2}$ & & $(8.0 \%)$ & $5(10.0 \%)$ & $0(0.0 \%)$ & $0(0.0 \%)$ & & \\
\hline$\cdot 1 \sim 2$ times/week & 19 & $(38.0 \%)$ & $11(22.0 \%)$ & $3(6.0 \%)$ & $3(6.0 \%)$ & & \\
\hline$\cdot 1 \sim 2$ times/month or rarely & 27 & $(54.0 \%)$ & $34(68.0 \%)$ & $47(94.0 \%)$ & $47(94.0 \%)$ & & \\
\hline
\end{tabular}


women in Maronge ate fish every day while in Lesen, $76.0 \%$ of men and $72.0 \%$ of women ate fish once or twice a week (men $\mathrm{p}<0.001$, women $\mathrm{p}<0.001)$. In Maronge, more men and women drank milk regularly while many in Lesen had never consumed milk. Intake of eggs and soybean products (Tahu/ Tempe) did not differ significantly between the two villages. Vegetables and fruits were consumed more frequently in Maronge than in Lesen.

Care-seeking behavior is shown in Figure 2. In Maronge, people would go to a private clinic or hospital for serious cases. In Lesen, people tended to go to a sub-health center or traditional healer (dukun) for any case.

No significant difference was indicated in the
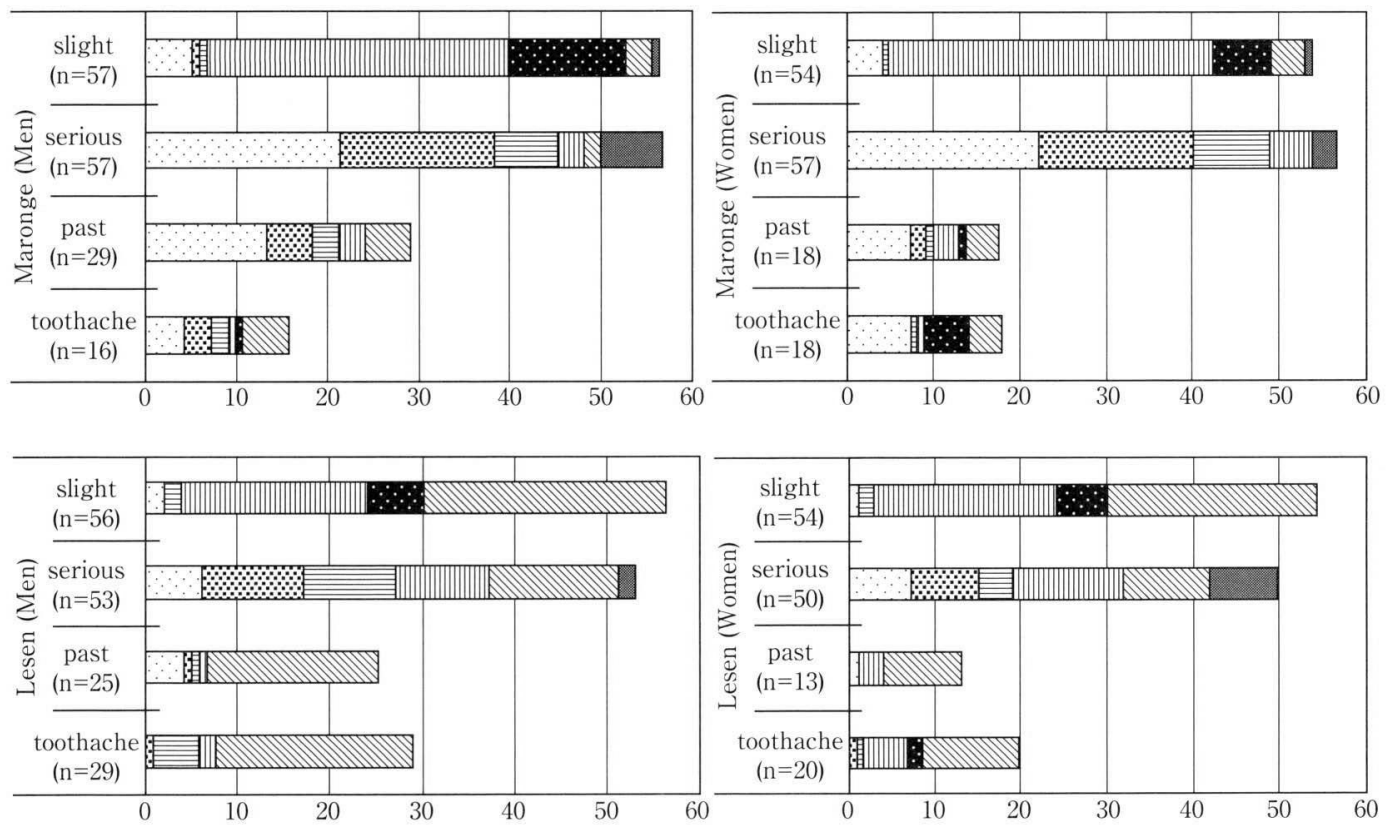

$\square$ hospital at other island, private hospital/clinic

酮 public hospital ${ }^{4)} \equiv$ health center ${ }^{5}$

血 sub-health center/midwife

$\because$ modern medicine

$\mathbb{W}$ dukun $^{7 /} /$ traditional medicine

don't know

Fig. 2 Comparison of care-seeking behavior in case of slight sickness, serious sickness, past case and toothache

1) Multiple answer for each query. P-values from Fisher's exact test are as follows; slight sickness (men: $<0.001$, women: <0.001), serious sickness (men: <0.001, women: <0.001), past case (men: <0.001, women: 0.044 ), toothache (men: 0.002, women: 0.001)

2) A vertical axis of the qraph expresses four cases in the questionaire, i.e., slight sickness, serious sickness, past illness, and toothache.

3) A horizontal axis of the qraph express number of answers.

4) Public hospital was located at Sumbawa Besar, the capital of the prefecture.

5) It took about an hour by public transportation from Maronge to the nearest health center in Plampang, and 1.5 hours from Lesen to the nearest health center in Sumbawa Besar.

6) There were a sub-health center and midwives each in Maronge and Lesen. A co-medical staff worked in a subhealth center.

7) Dukun is a kind of transitional healers using herbs and incantation to cure. 
subjective health status of the participants (Table 5). "Silu," arthralgia or arthritis similar to rheumatism, was the most common health problem in both villages. Some of the participants in Maronge had suffered from stroke, diabetes mellitus and hypertension. More women in Lesen were categorized in the hypertension group.

\section{Discussion}

Epidemiological transition has been occurring in developing countries. The burden of non-infectious diseases including chronic diseases has been increasing (Murray, 1997). Previous studies have shown an association of changes in health behavior and increases in obesity and chronic disease in developing countries surrounding Indonesia (Lewis and Rapaport, 1995; Sakamoto et al., 1997; Sakamoto et al., 2001, Ram et al., 1996).
In Indonesia, life expectancy has improved during this decade, from 59.8 years in 1986 to 64.2 years in 1997 (men and women). The primary cause of death changed from diarrhea in 1982 to cardiovascular disease in 1997 (Badan Pusat Statistik et al., 1998; Badan Pusat Statistik et al., 1995). Sutanegara et al. (2000) reported that diabetes mellitus and obesity have increased in Jakarta and in some urban areas in Indonesia. The Japan International Cooperation Agency (1998) reported that chronic diseases increase gradually with epidemiological transition. Under such a situation, improvement of health behavior is becoming more important in health promotion and disease prevention (Departemen Kesehatan, 1999; Darmojo et al., 1990)

According to the results of the Alameda County Study, regular physical activities, not smok-

Table 5 Comparison of health status (subjective health status, health problem, experience of serious sickness and blood pressure)

\begin{tabular}{|c|c|c|c|c|c|c|}
\hline & \multicolumn{2}{|c|}{ Maronge } & \multicolumn{2}{|c|}{ Lesen } & \multicolumn{2}{|c|}{$\mathrm{p}$ value ${ }^{1)}$} \\
\hline & Men & Women & Men & Women & Men & Women \\
\hline Subjective health status & & & & & 0.436 & 0.511 \\
\hline • very healthy & $2(4.0 \%)$ & $0(0.0 \%)$ & $0(0.0 \%)$ & $0(0.0 \%)$ & & \\
\hline - healthy & $34(68.0 \%)$ & $35(70.0 \%)$ & $39(78.0 \%)$ & $38(76.0 \%)$ & & \\
\hline - not very healthy & $11(22.0 \%)$ & $8(16.0 \%)$ & $10(20.0 \%)$ & $9(18.0 \%)$ & & \\
\hline$\cdot$ not healthy & $3(6.0 \%)$ & $7(14.0 \%)$ & $1(2.0 \%)$ & $3(6.0 \%)$ & & \\
\hline Health problem (multiple answer) & & & & & 0.143 & 0.024 \\
\hline$\cdot$ silu $^{2)} /$ arthralgia & 32 & 27 & 31 & 17 & & \\
\hline - stomach ache & 5 & 7 & 4 & 7 & & \\
\hline - general complaiant & 4 & 9 & 5 & 7 & & \\
\hline - lifestyle-related diseases ${ }^{3)}$ & 4 & 4 & 0 & 1 & & \\
\hline$\cdot$ others $^{4)}$ & 8 & 17 & 18 & 11 & & \\
\hline Experience of serious sickness & $24(48.0 \%)$ & $15(30.0 \%)$ & $22(44.0 \%)$ & $11(22.0 \%)$ & 0.688 & 0.260 \\
\hline Systolic blood pressure & & & & & 0.978 & $0.010 *$ \\
\hline$\cdot$ low $(\sim 119)$ & $22(44.0 \%)$ & $24(48.0 \%)$ & $23(46.0 \%)$ & $21(42.0 \%)$ & & \\
\hline$\cdot$ normal $(120 \sim 139)$ & $22(44.0 \%)$ & $21(42.0 \%)$ & $21(42.0 \%)$ & $12(24.0 \%)$ & & \\
\hline$\cdot \operatorname{high}(140 \sim)$ & $6(12.0 \%)$ & $5(10.0 \%)$ & $6(12.0 \%)$ & $17(34.0 \%)$ & & \\
\hline $\begin{array}{l}\text { * }: p<0.05 \\
\text { 1) Comparison of subjective health } \\
\text { Comparison of experience of seri } \\
\text { 2) Silu is arthralgia or arthritis simil } \\
\text { 3) lifestyle-related diseases include, } \\
\text { 4) others include headache, low bac }\end{array}$ & $\begin{array}{l}\text { atus and heal } \\
\text { is sickness an } \\
\text { to rheumati } \\
\text { yertension, s } \\
\text { pain, etc. }\end{array}$ & $\begin{array}{l}\text { problems w } \\
\text { systolic bloo } \\
\text { n. } \\
\text { roke and dial }\end{array}$ & $\begin{array}{l}\text { tested by } \mathrm{F} \\
\text { ressure wer }\end{array}$ & $\begin{array}{l}\text { er's exact t } \\
\text { ested by a c }\end{array}$ & re test. & \\
\hline
\end{tabular}


ing, appropriate alcohol drinking, sleeping 7-8 hours per night, eating breakfast daily, not eating between meals and appropriate body weight contribute to future health status (Belloc and Breslow L, 1972; Belloc, 1973; Willey and Camacho, 1980; Berkman and Breslow L, 1983; Breslow $\mathrm{L}$ and Breslow N, 1993). Most participants in the current study participated in regular physical exercises, ate breakfast daily, did not eat between meals and were not overweight. Although the mean hours of sleeping per night were under 7 hours, they supplemented their sleep by napping. Only a few participants drank alcohol regularly, and they did not drink too much or too frequently. Compared with the previous studies in urban areas such as Jakarta (Darmawan, 1992), the number of participants who exercised regularly was higher, except among Lesen women. People in the studied areas usually go to the workplace twice a day, in the morning and in the afternoon. Moreover, men in rural areas usually gather to play soccer or volleyball in the evening. These facts might explain why the prevalence of regular physical exercise in rural areas was higher than in urban areas.

However, there were many patients who suffered from rheumatism-like symptoms named "silu." Most of them were over 35 years old but some were young men in their 20 's. They were observed to have swelling of knee or ankle with pain and some of them could not walk or bend their knee by especially severe swelling. According to a nurse of sub-health center in Maronge, silu is one of popular symptoms in farmers caused by chill in leg or lumbar in paddy field. These symptoms, along with their severity, have not been reported in health statistics. This is because most patients would not use medical services but preferred traditional medicine such as herb poultice as Darmawan et al (1992) reported about rheumatism patients, and health statistics in Indonesia are generally prepared using data from medical facilities.

In comparing the two villages, the current study suggests that development assistance may have affected the income levels in Maronge. Participants in Maronge have experienced income increases since irrigation water was started to supply in 1997. By contrast, income in Lesen decreased because of the damage to agriculture caused by a water shortage in 2000 . The current study also demonstrates the differences in health behavior between the two villages and suggests that some of the differences are affected by economic status. As Sato Y et al. (1999) and Watanabe et al. (2000) reported, in Indonesia, economic crisis in 1997 and drought in 1998 have impacted negatively on access to food and nutritional and health status accordingly. In Sumbawa Prefecture, the crisis still had a negative impact on household economy and health development. (Dinas Kesehatan Kabupaten Sumbawa, 2000) Considering these situation, the studied areas also might have been affected. While, Sumarto et al (1999) reported that the impact of economic crisis on rural areas except Java have been milder than urban areas. The current study could not found clear impacts of economic crisis in 1997 and drought in 1998 in the studied areas.

Women in Lesen did not have enough time to exercise, as shown in Table 3. They were busy working both at home and in the fields. Every day, women in Lesen walked 5-10 minutes from their homes to the fields. In Maronge, many farmers hired field laborers. Men went to the fields every day, mainly to supervise, and women went twice or three times per week. Field areas in Maronge were located approximately $2 \mathrm{~km}$ from the residential areas, so that participants in Maronge considered walking to 
the fields as exercise. Few men in Lesen napped (Table 3) because they worked at side jobs. People in Maronge tended to spend more cash on cigarettes and on between-meal snacks. Lewis and Rapaport (1995) reported that there had been a shift in diet from traditional foods to imported foods in the Pacific region. The current study indicates that the shift also occurred in Maronge. Mean values of BMI were higher in Maronge than in Lesen. This finding agrees with the Sobal and Stunkard study (1989), which showed that improvement of socio-economic situation led to increased obesity in developing countries.

Daily diet also differed between the two villages (Table 4). In Maronge, participants tended to eat more vegetables, fruits and milk, and to have animal protein every day. After the project, vegetables began to be grown in the village, making it easier for the inhabitants to purchase and eat more vegetables. Access to vegetables was therefore improved by the project.

People in Maronge tended to spend more money on medical services to treat disease. This finding agrees with the previous study indicating that income and availability are important determinants of care-seeking behavior (Chernichovsky and Meesook, 1986). It is more likely that they obtained the appropriate diagnoses and medical treatment. The reason more women in Lesen were diagnosed with hypertension was not clear in the current study. However, less-frequent exercise among women in Lesen was supposed as a possible predictive factor because it differed from those of the men in Lesen and both the men and women in Maronge.

Health status in Southeast Asia has been improving in accordance with economic growth (Hertzman and Siddiqi, 2000). Although a significant difference in health status was not found in the current study, there were a few patients suffering from chronic diseases such as diabetes mellitus, hypertension, and stroke in Maronge. As Thiede (1997) reported that personal health status was associated with personal economic status, health status in Maronge may change in the future due to the recent increase in income.

The current study has several limitations. First, some queries were applied on health-related lifestyles that were based on a previous study conducted in the United States, because we could not find any generalized questionnaires on health-related lifestyle in the studied areas. Some items were therefore not considered to be applicable to the cultural background of the current study participants. Alcohol drinking, in particular, was a sensitive matter for Muslims. Further studies should focus on the development of a generalized questionnaire on health behavior and health status that would be applicable anywhere.

'Second, sample size could not be decided in the planning stage because the current study was exploratory research and did not hold any particular causal association to analyze relative risks. According to Schlessman (1974) and Armitage and Berry (1994), chance for $\beta$ error would be less than $20 \%$ if the differences in odds ratios were more than 0.25 . It was considered, therefore, that in the current study the sample size might be enough to compare a specific difference of health behavior.

Third, the baseline data of economic and health status of both villages were unavailable, and thus they might have been different even before the project began. In addition, the indirect influence of development assistance on health behavior and health status was difficult to determine. In the current study, we focused on the opinions of some inhabitants in Maronge that 
there were changes in utilization of medical services, smoking behavior, daily diet and household economy after the project. Further study should focus on the development of a study method to clarify the indirect influence of development assistance.

\section{Conclusion}

The current study indicates that rural inhabitants in Sumbawa prefecture have a healthy lifestyle. However, "silu" is not identified in the health statistics. In comparing the two villages, differences were observed in both health behaviors and economic status. The current study suggests that development assistance might have affected health behavior through income generation.

\section{Acknowledgement}

The authors greatly appreciate the kind cooperation of the survey participants, and the staff members in the Small Scale Irrigation Management Project Office who gave valuable advice for the field investigation.

\section{References}

Armitage P, Berry G (1994): Statistical methods in medical research, 3rd edition, Blackwell Scientific Publications (Oxford)

Badan Pusat Statistik (BPS) (Central Bureau of Statistic), Badan Koordinasi Keluarga Berencana Nasional (BKKBN) (National Family Planning Coordinating Agency), Departemen Kesehatan (Ministry of Health), et al. (1995): Survey demografi dan kesehatan 1995 (Health and demographic survey 1995), BPS, BKKBN, Departemen Kesehatan, Macro International, Inc. (Jakarta)

Badan Pusat Statistik (BPS) (Central Bureau of Statistic), Badan Koordinasi Keluarga Berencana Nasional (BKKBN) (National Family Planning Coordinating Agency), Departemen Kesehatan (Ministry of Health), et al. (1998): Survey demografi dan kesehatan 1998 (Health and demographic survey1998), BPS, BKKBN, Departemen Kesehatan, Macro International, Inc. (Jakarta)

Badan Pusat Statistik (BPS) Kabupaten Sumbawa (Central Bureau of Statistic in Sumbawa Prefecture) (2000): Kecamatan Moyo Hulu dalam angka 2000 (Moyo Hulu District in figure 2000), BPS Kabupaten Sumbawa (Sumbawa Besar)

Badan Pusat Statistik (BPS) Kabupaten Sumbawa (Central Bureau of Statistic in Sumbawa Prefecture) (1999): Kecamatan Pelampang dalam angka 1999 (Plampang District in figure 1999), BPS Kabupaten Sumbawa (Sumbawa Besar)

Belloc NB (1973): Relationship of health practices and mortality, Preventive Medicine, 2, 76-81

Belloc NB, Breslow L (1972): Relationship of physical health status and health practices, Preventive Medicine, 1, 409-421

Berkman L F and Breslow L (1983): Health and way of living: The Alameda County Study, Oxford University Press, Inc. (New York)

Breslow L, Breslow N (1993): Health practices and disability: some evidence from Alameda County, Preventive Medicine, 22, 86-95

Chernichovesky D, Meesook OA (1986): Utilization of health services in Indonesia, Social Science and Medicine, 23, 611-620

Dinas Kesehatan Kabupaten Sumbawa (Health Bureau of Sumbawa Prefecture) (2000): Laporan tahunan pelaksanaan kegiatan tahun 1999/2000 (Annual report 1999/2000), Dinas kesehatan Kabupaten Sumbawa (Sumbawa Besar)

Darmawan J, Valkenburg HA, Muirden KD, et al. (1992): Epidemiology of rheumatic diseases in rural and urban population in Indonesia, a WHO International League Against Rheumatism COPCORD Study I-2, Annals of the Rheumatic Diseases, 51, 525-528

Darmojo RB (1993): The pattern of cardiovascular disease in Indonesia, World Health Quarterly, 46, 119-124

Darmojo RB, B Setianto, Sutedjo, et al. (1990): A study of baseline risk factors for coronary heart disease: results of population screening in a developing country, Rev. Epidem. Et Sante Publ., 38, 487-491 
Departemen Kesehatan (Ministry of Health) (1995): Panduan 13 pesan dasar gizi seimbang (13 basic guidelines for balanced diet), Departemen Kesehatan (Jakarta)

Departemen Kesehatan (Ministry of Health) (1999): Rencana pembangunan kesehatan menuju Indonesia sehat 2010 (Healthy Indonesia 2010), Departemen Kesehatan (Jakarta)

Hertzman C, Siddiqi A (2000): Health and rapid economic change in the late twentieth, Social Science and Medicine, 51, 809-819

Japan International Cooperation Agency (JICA) (1998): Shiin-shippei (Mortality and disease), Kunibetsu iryo kyoryoku fairu - Indonesia (Country medical cooperation file-Indonesia), 30-50, JICA (Tokyo)

Juguan A, Widjajalukito, Schultink W (1999): Thiamine deficiency is prevalent in a selected group of urban Indonesian elderly people, The Journal of Nutrition, 129(2), 366-371

Karyadi E, Schultink W, Nelwan RH, et al. (2000): Poor micronutrient status of active pulmonary tuberculosis patients in Indonesia, Journal of Community and International Nutrition, 130, 2953-2958

Kaye K, Novell M K (1994): Health practices and indices of a poor urban population in Indonesia, part I: patterns of health service utilization, Asia Pacific Journal of Public Health, 7(3), 17882

Kikuchi Y (1998): Evaluation method on ODA from the view point of Development Anthropology, International Development Study, 7(12), 49-61

Launer L J, Habicht J P (1989): Concepts about infant health, growth and weaning: a comparison between nutritional scientists and Madurese mothers, Social Science and Medicine, 29(1), 13-22

Lewis D N, Rapaport M (1995): In a sea of change: health transitions in the Pacific, Health and Place, 1(4), 211-226

Murray CJL, Lopez AD (1997): Global mortality, disability and the contribution of risk factors, The Lancet, 349, 1436-42

Persson V, Winkvist A, T Ninuk, et al. (2001): Variability in nutrient intakes among pregnant woman in Indonesia: implications for the design of epidemiological studies using the 24h recall method, Journal of Nutritional Epi- demiology, 131, 325-330

Ram B Singh, Mori H, Junshi Chen, et al. (1996): Recommendations for the prevention of coronary artery disease in Asias: a scientific statement of the International College of Nutrition, Journal of Cardiovascular Risk, 3, 489-494

Roosihermiatie B, Nishiyama M, Nakae K (2000): The human behavioral and socioeconomic determinants of Malaria in Bacan Island, North Maluku, Indonesia, Journal of Epidemiology, 10(4), 280-289

Sakamoto N, Khor Geok Lin, Marui E (1997): Body physique and lifestyle of urban preschool children in Japan and Malaysia, Minzoku Eisei, (Japanese Journal of Health and Human Ecology), 63(3), 157-165

Sakamoto N, S Wansorn, K Tontisirin et al. (2001): A social epidemiologic study of obesity among preschool children in thailand, International Journal of Obesity, 25, 389-394

Sato Y, Nakamura Y, Alfin A (1999): Indonesia chubu Jawa shu no keizaikikika ni okeru eiyo sicchouji no zoka jittai (Actual situation of increasing of malnutrition children under economic crisis in Central Java, Indonesia), Nettai, 32, 162-167

Sato H (1996): Kaihatsuenjo to shakaigaku (Development assistance and sociology), Sato ed., Enjo Kenkyu Nyumon-Enjo Kenkyu no Gakusaiteki Apurochi (Handbook for Development Assistance Study - Academic Approach of Development Assistance Study), 105-164, Institute of Economies (Tokyo)

Saw SM, Koh D, Adjani MR, Wong ML, et al. (2001): A population-based prevalence survey of skin disease in adolescents and adults in rural Sumatra, Indonesia, 1999, Transactions of the Royal Society of Tropical Medicine and Hygiene, 95(4), 384-388

Schlesseman JJ (1974): Sample size requirements in cohort and case-control studies of disease, American Journal of Epidemiology, 99, 381-384

Sobal J, Stunkard AJ (1989): Socioeconomic status and obesity: A review of the literature, Psychol Bull, 105(2), 260-275

Strisna B, Reingold A, Kresno S, et al. (1993): Care-seeking behavior for fatal illness in young children in Indramayu, West Java, Indonesia, The Lancet, 342, 787-789

Sudomo M, Kasnodiharjo, Oemijatis (1993): Social 
and behavioral aspects of filariasis transmission in Kumpeh, Jambi, Indonesia, Southeast Asian Journal of Tropical Medicine and Public Health, 24 Suppl, 226-30

Sularyo TS (1996): Growth and development of underfives in marunda area in North Jakarta, Medical Journal of Indonesia, 5(1), 55-62

Sumarto S, Wetterberg A, Pritchett L (1999): The social impact of the crisis in Indonesia: results from a nationwide kecamatan survey, 118, World Bank (Wasington)

Sutanegara D, Darmono, Budhiarta AAG (2000): The epidemiology and management of diabetes mellitus in Indonesia, Diabetes Research and Clinical Practice, 50 (Suppl. 2), S9-S16

Tamura K (1996): Monshin no shikata (The way of asking patient condition), Nagai $\mathrm{R}$ ed., Kenshui noto (Handbook for resident) 2nd ed., 166 -182 , Chiryo to shindan sha (Tokyo)

Thiede M (1997): Mutual influence of health and poverty, evidence from German Panel Data, Social Science and Medicine, 45(6), 867-877

Toma T, Miyagi I, Kamimura K, et al. (1999): Questionnaire survey and prevalence of in- testinal helminthes infections in Barru, Sulawesi, Indonesia, Southeast Asian Journal of Tropical Medicine and Public Health, 30(1), 6877

Wakai K, Dillon DS, Ohno Y, et al. (2000): Fat intake and breast cancer risk in an area where fat intake is low: a case-control study in Indonesia, International Journal of Epidemiology, 29, 20-28

Watanabe Y, Sato Y, Nakamura Y, Hj. Rasyidah R (2000): Indonesia ni okeru eiyo shicchoji no taisaku - Nishi Sumatra shu no jirei (Provision for malnutrition children in Indonesia - case study in West Smatra Province), Nettai, 33, 123 $-129$

Willey JA, Camacho TC (1980): Life-style and future health: evidence from the Alameda County, Preventive Medicine, 9, 1-21

World Bank (1994): Infrastructure: achievements, challenges, and opportunities, World Development Report, 13-36, Oxford University Press (New York)

(Received 12. 25, 2001; Accepted 11. 15, 2002) 